\title{
KARAKTERISTIK PENYULUH DALAM PEMANFAATAN MEDIA SOSIAL SEBAGAI MEDIA INFORMASI PERTANIAN
}

\section{(The Extension Agents Characteristics In The Social Media Utilization As Agricultural Information Media)}

\author{
${ }^{1}$ Lutfi Humaidi, ${ }^{2}$ Aida Vitayala S Hubeis, ${ }^{2}$ Herien Puspitawati, ${ }^{2}$ Oos E M Anwas \\ ${ }^{1}$ Balai Pengkajian Teknologi Pertanian Kepulauan Riau, Indonesia \\ ${ }^{2}$ Fakultas Ekologi Manusia Institut Pertanian bogor, Indonesia \\ Email: humaidi.lut@gmail.com
}

Diterima 16 Oktober 2019, disetujui 20 Mei 2020

\begin{abstract}
ABSTRAK
Perkembangan teknologi informasi dan komunikasi (TIK) yang sangat pesat khususnya media sosial berpotensi untuk dimanfaatkan penyuluh sebagai media informasi pertanian guna memecahkan permasalahan petani yang terjadi di lapangan. Penelitian bertujuan untuk (1) menganalisis karakteristik penyuluh, dan pemanfaatan media sosial sebagai media informasi pertanian, (2) menganalisis pengaruh karakteristik penyuluh terhadap pemanfaatan media sosial sebagai media informasi pertanian. Penelitian dilaksanakan dengan menggunakan metode sensus yakni seluruh penyuluh yang berada di Provinsi Kepulauan Riau yang berjumlah 90 orang. Variabel penelitian terdiri dari variabel bebas yaitu karakteristik penyuluh $(\mathrm{X})$, dan variabel terikat yaitu pemanfaatan media sosial $(\mathrm{Y})$. Pengumpulan data primer penelitian dilakukan dengan wawancara terstruktur, observasi dan wawancara mendalam. Data sekunder dikumpulkan melalui berbagai dokumen yang terkait dengan penelitian yang berasal dari instansi pemerintah. Analisis data mencakup: (1) analisis deskriptif berupa distribusi frekuensi, persentase dan rataan skor dengan bantuan Microsoft Excel dan Statistical Package for The Social Science (SPSS) versi 20.0. dan (2) Analisis inferensial dengan Partial Least Square (PLS) melalui bantuan aplikasi SmartPLS 3.0. Hasil penelitian menunjukkan bahwa karakteristik penyuluh dalam kategori rendah, sedangkan pemanfaatan media sosial dalam kategori sedang. Pemanfaatan media sosial yang terefleksikan melalui facebook, whatsapp dan youtube dipengaruhi oleh karakteristik penyuluh yang terefleksikan melalui umur, pengalaman sebagai penyuluh dan kosmopolitan. Penyuluh perlu lebih meningkatkan dan memperluas pengalaman bekerja sebagai penyuluh. Perlu membangun kesadaran penyuluh pertanian untuk terus belajar secara bertahap, berkualitas dan berkelanjutan terkait usahatani salah satunya melalui pemanfaatan media sosial. Perlu diberikan informasi kepada penyuluh bahwa di media sosial instagram juga banyak informasi pertanian yang dapat diakses oleh penyuluh.
\end{abstract}

Kata kunci: informasi pertanian, karakteristik penyuluh, media sosial

\section{ABSTRACT}

The rapid development of information and communication technology (ICT), especially social media, has the potential to be used by extension agents as agricultural information media to solve farmers' problems that occur in the field. The aims of research are (1) analyze the extension agent characteristics, and the use of social media as agricultural information media, (2) analyze the influence of extension agents characteristics on the use of social media as agricultural information media. The research was carried out using the census method that is all extension workers in Riau Islands Province, amounting to 90 people. The research variables consist of independent variables, namely the extention agents characteristics $(X)$, and the dependent variable, namely the use of social media $(Y)$. The primary 
data collection research was carried out by structured interviews, observations and in-depth interviews. Secondary data was collected through various documents related to research originating from government agencies. Data analyzed includes: (1) descriptive analyzed in the form of frequency distribution, percentage and average score with the help of Microsoft Excel and Statistical Package for Social Science (SPSS) version 20.0. and (2) inferential analyzed with Partial Least Square (PLS) through the help of the SmartPLS 3.0 application. The results showed that the extension agents characteristics were in the low category, while the use of social media was in the medium category. Utilization of social media that was reflected through facebook, whatsapp and youtube ware influenced by the extension agents characteristics that was reflected through age, experience as counselors and cosmopolitan. The extension agents need to further enhance and expand their experience working as extension agents. Need to build awareness of agricultural extension agents to continue learning gradually, quality and sustainable farming related to one of them through the use of social media. It is necessary to provide information to the instructor that on instagram social media there is also a lot of agricultural information that can be accessed by extension agents.

Keywords: agricultural information, extension agents characteristics, social media

\section{PENDAHULUAN}

Sumber daya manusia (SDM) yang berkualitas adalah yang minimal memiliki empat karakteristik, yaitu: (1) competency (knowledge, skill, abilities dan experience) yang memadai; (2) commitment pada organisasi; (3) selalu bertindak costeffectiveness pada setiap aktivitasnya dan (4) congruence of goals yaitu bertindak selaras antara tujuan pribadi dengan tujuan organisasi (Lako dan Sumaryati, 2002). Berhasil tidaknya suatu organisasi mencapai visi dan misinya secara berkelanjutan sangat tergantung pada kualitas sumberdaya manusianya (SDM). Dalam rangka mewujudkan pertanian yang tangguh, maka diperlukan upaya pengembangan SDM pertanian yang profesional, kreatif, inovatif, kredibel dan berwawasan global (Hartati, et al. 2011). Tantangan SDM pertanian khususnya penyuluh akan menjadi semakin kompleks seiring dengan kemajuan teknologi informasi dan komunikasi (TIK). Menurut Anwas (2009) bahwa dinamika masyarakat dan perkembangan teknologi informasi dan komunikasi berimplikasi pada perlunya perubahan sistem penyuluhan, terutama SDM penyuluh yang handal, karena penyuluh sebagai ujung tombak pelaksanan penyuluhan di lapangan.

Perkembangan TIK yang sangat pesat khususnya media sosial berpotensi untuk dimanfaatkan penyuluh sebagai media informasi pertanian guna memecahkan permasalahan petani yang terjadi di lapangan. Muslihat, et al. (2015) menjelaskan bahwa kompetensi seorang penyuluh agar bisa dipandang berkompeten oleh masyarakat tergantung pada faktor konsumsi media. Semakin sering seorang penyuluh memanfaatkan media, maka semakin banyak pengetahuan yang dimiliki, dan kesempatan untuk menjawab permasalahan petani juga menjadi semakin besar.

Teknologi informasi dan komunikasi (TIK) berkembang seiring perubahan yang terjadi di masyarakat. Hubeis (2010) menyatakan bahwa perilaku masyarakat dalam memanfaatkan informasi dan teknologi mendukung pengembangan masyarakat secara global. TIK yang sedang berkembang pesat saat ini adalah media sosial. Berdasarkan hasil penelitian yang dilakukan oleh Wearesosial dan Hootsuite (2019) menyebutkan bahwa ada 150 juta orang Indonesia yang aktif menggunakan media sosial.

Media sosial dapat digunakan untuk bertukar informasi, kolaborasi dan saling berkenalan dalam bentuk tulisan visual maupun audiovisual, seperti melalui twitter, facebook, blog, instagram, whatsapp, dan lainnya (Puntoadi 2011). Melalui media sosial seseorang dapat saling membagi ide, bekerjasama, dan berkolaborasi untuk menciptakan kreasi, berpikir, berdebat, menemukan orang yang bisa menjadi teman 
baik, menemukan pasangan dan membangun sebuah komunitas (Nasrullah, 2017).

Penelitian Veronice (2013) menyatakan bahwa salah satu unsur penting yang harus dimiliki oleh penyuluh pertanian adalah kemampuan dalam mengakses teknologi informasi dan komunikasi di bidang pertanian untuk mendukung perannya dalam memberikan layanan informasi sesuai dengan kebutuhan petani dan mengikuti perkembangan ilmu pengetahuan teknologi dan komunikasi yang berlangsung cepat. Untuk menunjang pencapaian tersebut, penyuluh pertanian dapat mencari dan mengakses sumber-sumber informasi dari media online sehingga pada nantinya petani mampu meningkatkan daya saing usaha taninya.

Seorang penyuluh memiliki karakteristik yang berbeda-beda dalam memanfaatkan media sosial. Menurut Lionberger yang diacu Bahua dan Limonu (2016) mengemukakan bahwa, karakteristik individu adalah personal faktor yang berhubungan dengan semua aspek kehidupan dan lingkungan seperti: umur, pendidikan dan karakteristik psikologis. Listiana (2018) menjelaskan karakteristik individu penyuluh merupakan sifat-sifat yang melekat pada diri seseorang penyuluh, antara lain: umur, pendidikan, masa kerja, tingkat motivasi, dan kosmopolitan.

Pemanfaatan sistem informasi dan teknologi melalui media sosial pada hakekatnya akan menunjang pembangunan pertanian jika dimanfaatkan sebagaimana mestinya. Persoalan yang muncul kemudian adalah tidak semua karakteristik penyuluh pertanian mampu memanfaatkan teknologi informasi ini. Penelitian Listiana (2018) menyatakan bahwa penyuluh di Provinsi Lampung memiliki kecenderungan yang rendah dalam pemanfaatan teknologi informasi dan komunikasi. Berbeda dengan penelitian Wijaya (2015) bahwa penyuluh dalam mengakses Cyber Extension tergolong baik, kebanyakan para penyuluh sudah mampu mengoperasikan komputer untuk akses internet, mengakses informasi terbaru, menggunakan email, dan berkomunikasi dengan sesama penyuluh. Sementara itu menurut Anwas (2009) menyatakan bahwa penyuluh harus memiliki inisiatif dan aktif untuk mencari berbagai media belajar untuk meningkatkan kompetensinya untuk memfasilitasi kebutuhan informasi petani.

Berdasarkan latar belakang tersebut, maka penelitian ini bertujuan untuk menganalisis tingkat karakteristik penyuluh, dan pemanfaatan media sosial sebagai media informasi pertanian, dan menganalisis pengaruh karakteristik penyuluh terhadap pemanfaatan media sosial sebagai media informasi pertanian di Provinsi Kepulauan Riau.

\section{METODEPENELITIAN}

Penelitian ini menggunakan pendekatan kuantitatif dengan teknik wawancara berkuesioner. Penelitian ini diperkuat dengan data kualitatif yang diperoleh dari observasi dan wawancara mendalam (indepth interview) kepada informan kunci. Berdasarkan tujuan yang ingin dicapai, rancangan penelitian yang dipilih adalah kombinasi antara penelitian deskriptif (descriptive research) dan penelitian eksplanatori (explanatory research). Penelitian deskriptif bertujuan memecahkan atau menjawab permasalahan yang sedang dihadapi pada situasi sekarang dengan tujuan utama membuat gambaran tentang sesuatu keadaan secara objektif (Tukiran dan Hidayati, 2012). Penelitian eksplanatori bertujuan menjelaskan dan menguraikan hubungan kausal, atau hubungan variabel bebas dengan variabel terikat dan pengujian hipotesis (Effendi dan Tukiran, 2012). Variabel bebas penelitian ini yaitu karakteristik penyuluh $(\mathrm{X})$, dan variabel terikat pemanfaatan media sosial (Y).

Lokasi penelitian di Provinsi Kepulauan Riau. Secara administratif, lokasi penelitian meliputi dua kota yaitu Tanjungpinang dan Batam dan lima kabupaten yaitu Bintan, Karimun, Lingga, Natuna, dan Kepulauan Anambas. Waktu penelitian dilaksanakan selama lima bulan, dimulai pada bulan Juni sampai Oktober 2019. Tahapan penelitian 
mulai dari uji coba kuesioner, pengumpulan data, pengolahan data, dan analisis data. Unit analisis pada penelitian adalah penyuluh pertanian di Provinsi Kepulauan Riau. Penelitian ditentukan dengan metode sensus yakni seluruh penyuluh yang berjumlah 90 orang yang terdiri dari penyuluh Pegawai Negeri Sipil (PNS) dan penyuluh Tenaga Harian lepas-Tenaga Bantu Penyuluh Pertanian (THL-TBPP). Jumlah penyuluh di Provinsi Kepulauan Riau secara rinci dapat dilihat pada Tabel 1.

Pengumpulan data primer penelitian dilakukan dengan teknik pertama, wawancara terstruktur dengan menggunakan alat bantu kuisioner dan dipandu langsung oleh peneliti atau enumerator; Kedua, melakukan pengamatan langsung di lapangan; Ketiga wawancara mendalam dilakukan kepada: 1) Kepala Dinas Pertanian dan Ketahanan Pangan Kabupaten Bintan, Lingga, dan Natuna; 2) Kepala Balai Pengkajian Teknologi Pertanian (BPTP) Kepulauan Riau; 3) Koordinator penyuluh di Kota Tanjungpinang dan Batam, dan Kabupaten Bintan, Karimun, Lingga, Natuna, dan Kepulauan Anambas. Data sekunder dikumpulkan melalui berbagai dokumen yang terkait dengan penelitian yang berasal dari instansi pemerintah. Sumber data sekunder ini diperoleh dari instansi terkait seperti Pusat Penyuluhan Pertanian, Dinas Pertanian, BPTP, Balai Penyuluhan Pertanian (BPP) yang ada di masing-masing kota dan kabupaten di Provinsi Kepulauan Riau.
Data yang diperoleh dianalisis menggunakan statistik deskriptif dan statistik inferensial. Statistik dekriptif dengan menggunakan tabel distribusi frekuensi, persentase dan rataan skor digunakan untuk menjawab tujuan pertama yaitu memberikan gambaran mengenai sebaran penyuluh pada setiap variabel yang digunakan. Analisis data statistik deskriptif menggunakan Microsoft Excel dan Statistical Package for The Social Science (SPSS) versi 20.0. Selanjutnya statistik inferensial digunakan untuk menjawab tujuan kedua yaitu menganalisis pengaruh variabel bebas terhadap variabel terikat. Analisis data penelitian secara statistika inferensial dengan Partial Least Square (PLS) melalui bantuan aplikasi SmartPLS 3.0. (Ghazali, 2015).

Partial Least Square (PLS) adalah model persamaan Structural Equation Modeling (SEM) yang berbasis komponen atau varian dan dapat menjawab penelitian dalam bidang sosial atau variabel yang sulit diamati secara langsung dengan melihat nilai pengaruh yang terjadi diantara kedua variabel yang diamati (Santosa, 2018). Untuk menjawab rumusan masalah penelitian, dalam PLS dapat melakukan evaluasi model dengan pengujian model pengukuran (outer model) dan model struktural (inner model) yang dibantu dengan software smartPLS V.3.0. Pengujian (outer model) untuk mengetahui hubungan antara indikator dengan variabel yang diwakilkan. Pengujian outer model terdapat tiga uji yaitu uji validitas konvergen dengan melihat nilai

Tabel 1. Jumlah Penyuluh di Provinsi Kepulauan Riau Tahun 2019

\begin{tabular}{lrcr}
\hline \multicolumn{1}{c}{ Kategori } & $\begin{array}{c}\text { PNS } \\
\text { (Orang) }\end{array}$ & $\begin{array}{c}\text { THL-TBPP } \\
(\text { Orang) }\end{array}$ & $\begin{array}{c}\text { Jumlah } \\
\text { (Orang) }\end{array}$ \\
\hline Kota Tanjungpinang & 0 & 6 & 6 \\
Kota Batam & 2 & 5 & 7 \\
Kabupaten Bintan & 4 & 8 & 12 \\
Kabupaten Karimun & 23 & 9 & 32 \\
Kabupaten Lingga & 0 & 9 & 9 \\
Kabupaten Natuna & 0 & 8 & 8 \\
Kabupaten Anambas & 0 & 16 & 16 \\
Total (orang) & 29 & 61 & 90 \\
\hline
\end{tabular}


loading factor $>0,7$ untuk masing-masing indikator, uji validitas diskriminan dengan melihat nilai cross loading $>0.7$ dan reliabilitas dengan melihat nilai composit reliability dan chronbha alpha $>0.5$.

Pengujian model struktural (inner model) untuk melihat pengaruh yang terjadi diantarakedua variabel yang terhubung. Pengujian model struktural (inner model) dengan melihat nilai $\mathrm{R}^{2}$ untuk masing-masing variabel terikat, uji kedua dalam inner model adalah uji GoF (Goodness of Fit) untuk melihat kebaikan dari model jalur yang dibangun dengan melihat nilai SRMR, ChiSquare dan NFI dan ketiga adalah uji Path Coefficient untuk mengetahui seberapa besar pengaruh dan hubungan yang terjadi antara variabel bebas dan variabel terikat yang diteliti dengan melihat nilai original sample, t-statistic dan P-value. Semua uji model tersebut dapat menjawab rumusan masalah yang diteliti dan mengkonfirmasi teori (Santosa, 2018).

\section{HASIL DAN PEMBAHASAN}

\section{Karakteristik Penyuluh}

Karakteristik penyuluh merupakan bagian dari ciri pribadi yang melekat pada diri seseorang. Karakteristik tersebut mendasari tingkahlaku seseorang dalam situasi kerja maupun situasi yang lainnya. Karakteristik penyuluh dalam penelitian ini terdiri dari: umur, tingkat pendidikan, dan pengalaman sebagai penyuluh, dan kekosmopolitan. Deskripsi karakteristik penyuluh secara jelas dapat dilihat pada Tabel 2.

Berdasarkan Tabel 2 bahwa umur penyuluh di lokasi penelitian paling banyak pada usia dewasa awal (29-38 tahun). Penyuluh yang bertugas di Kabupaten Bintan dan Karimun ada 13 orang diperkirakan dalam kurun waktu tiga sampai delapan tahun ke depan masuk pada usia pensiun. Penyuluh yang bertugas di tiga kabupaten tersebut mayoritas pada usia pertengahan (39-48 tahun), sedangkan yang penyuluh yang bertugas di Lingga, Natuna dan Anambas

Tabel 2. Sebaran Karakteristik Penyuluh di Provinsi Kepulauan Riau Tahun 2019

\begin{tabular}{|c|c|c|c|}
\hline Karakteristik Penyuluh & Kategori & $\begin{array}{c}\text { Jumlah } \\
\text { (Orang) } \\
n=90\end{array}$ & $\begin{array}{c}\text { Persentase } \\
\quad(\%)\end{array}$ \\
\hline Umur & Muda (19-28 tahun) & 16 & 18 \\
\hline \multirow[t]{3}{*}{ Rataan 31 tahun } & Dewasa awal (29-38 tahun) & 33 & 37 \\
\hline & Usia pertengahan (39-48 tahun) & 28 & 31 \\
\hline & Usia menjelang tua (49-58 tahun) & 13 & 14 \\
\hline Pendidikan Formal & SMA & 25 & 28 \\
\hline \multirow[t]{3}{*}{ Rataan S1 } & D3 & 3 & 3 \\
\hline & $\mathrm{D} 4 / \mathrm{S} 1$ & 61 & 68 \\
\hline & $\mathrm{S} 2$ & 1 & 1 \\
\hline Pengalaman Sebagai & 1-7 tahun & 57 & 63 \\
\hline Penyuluh & 8-14 tahun & 29 & 32 \\
\hline \multirow[t]{2}{*}{ Rataan 2 tahun } & 15-21 tahun & 1 & 1 \\
\hline & $22-28$ tahun & 3 & 3 \\
\hline Kosmopolitan & Sangat rendah (skor 8-30) & 24 & 27 \\
\hline \multirow[t]{3}{*}{ Rataan skor 39} & Rendah (skor 31-53) & 35 & 39 \\
\hline & Sedang (skor 54-79) & 26 & 29 \\
\hline & Tinggi (skor 78-100) & 5 & 4 \\
\hline
\end{tabular}

Sumber: Data Primer Diolah (2019)

Keterangan: Rataan Skor :0 - 25 = Sangat rendah, $26-50=$ Rendah, $51-75=$ Sedang, $76-$ $100=$ Tinggi 
mayoritas pada usia dewasa awal (29-38 tahun). Penyuluh yang berada pada usia muda dan dewasa awal saat ini masih mendapatkan pendampingan dari penyuluh yang berusia pertengahan dan menjelang tua.

Dari aspek pendidikan formal, rata-rata 25 persen masih ada penyuluh yang memiliki tingkat pendidikan SMA, dan 3 persen berpendidikan Diploma (D1-D3), penyuluh yang sudah berpendidikan setingkat sarjana ada 61 persen, sedangkan penyuluh yang sudah berpendidikan magister (S2) hanya ada 1 persen. Secara umum tingkat pendidikan formal penyuluh mayoritas sudah kategori sedang. Tingkat pendidikan formal penyuluh yang bertugas di Kabupaten Lingga, Natuna dan Anambas lebih tinggi dibandingkan dengan yang bertugas di Kabupaten Bintan, Karimun, dan Kota Batam. Tingginya tingkat pendidikan formal bagi penyuluh di Kabupaten Lingga, Natuna dan Anambas dikarenakan banyaknya penyuluh yang baru bekerja sebagai penyuluh dan disyaratkan memiliki izasah minimal setingkat sarjana. Masih rendahnya tingkat pendidikan formal di Bintan, Karimun, dan Batam dikarenakan masih rendahnya minat penyuluh untuk melanjutkan studi lebih lanjut setelah diangkat menjadi penyuluh. Penyuluh senior rata-rata motivasinya masih rendah dalam melanjutkan jenjang pendidikan formal. Penyuluh lebih suka mengikuti pendidikan nonformal, seperti workshop dan Diklat, karena materi dan kurikulum yang didapatkan dianggap lebih aplikatif.

Berdasarkan Tabel 2 pengalaman kerja sebagai penyuluh di Kabupaten Bintan, Karimun, dan Kota Batam lebih lama dibandingkan dengan yang bertugas di kabupaten Lingga, Natuna, dan Anambas. Penyuluh yang bertugas Hal ini karena penyuluh yang bertugas Bintan, Karimun dan Batam masih ada 29 orang adalah penyuluh PNS sedangkan semua penyuluh yang bertugas Lingga, Natuna dan Anambas semuanya penyuluh Tenaga Honor LepasTenaga Bantu Penyuluh Pertanian (THLTBPP). Penyuluh THL-TBPP bekerjanya berdasarkan kontrak sehingga ketika kontrak habis kadang ada yang masih diperpanjang dan kadang ada yang mengajukan pengunduran diri (resign). Penyuluh yang berstatus PNS tidak ada masa kontrak dan tidak ada yang berkeinginan untuk mengundurkan diri.

Pengalaman kerja penyuluh merupakan sesuatu yang pernah dialami, dijalani, dirasakan dalam menjalankan kegiatan penyuluhan dengan mengerakkan tenaga dan pikiran untuk menyakinkan petani akan materi-materi maupun informasi-informasi yang disampaikan sesuai dengan tujuan yang telah ditetapkan. Sesuatu yang pernah dialami seseorang akan mempengaruhi penghayatan terhadap lingkungan sosial dan lingkungan kerjanya. Penyuluh yang memiliki masa kerja yang lama cenderung mendapatkan kepercayaan lebih dari petani dibandingkan yang baru bekerja. Kejadian yang telah dialami penyuluh akan membentuk dan memengaruhi penghayatan terhadap stimulus sosial.

Secara umum, penyuluh memiliki sikap kosmopolitan berada pada rataan skor 39 (rendah). Penyuluh yang bertugas di Kabupaten Bintan, Karimun, Kota Tanjungpinang, dan Batam tingkat kosmopolitan lebih baik, hal ini disebabkan penyuluh Kabupaten/kota tersebut lebih mudah berinteraksi dengan media internet, karena lebih lancar dan operator bervariatif dibanding dengan yang bertugas di Kabupaten Lingga, Natuna, dan Anambas. Selain itu penyuluh yang ada Kabupaten Bintan, Karimun, dan Kota Tanjungpinang dan Batam relatif lebih dekat dengan ibu kota Provinsi Kepulauan Riau, dekat dengan kantor BPTP Kepri, Dinas Pertanian Provinsi Kepri dan beberapa perusahaan agribisnis, serta berdekatan dengan negara tetangga Malaysia dan Singapura. Sikap kosmopolit penyuluh lokasi penelitian dapat dibuktikan juga dengan melihat intensitas berkomunikasi dengan organisasi Perhimpunan Penyuluh Pertanian Indonesia (Perhiptani), Kontak Tani dan Nelayan Andalan (KTNA), akses cyber extention, dan penggunaan aplikasi startup pertanian. 


\section{Pemanfaatan Media Sosial}

Media sosial memiliki potensi untuk dijadikan sebagai stimulus dalam proses perubahan perilaku penyuluh pertanian. Beragamnya jenis media sosial diantaranya yaitu: facebook, whatsapp, youtube, dan instagram memungkinkan untuk dimanfaatkan penyuluh sebagai media belajar dan sumber informasi pertaian. Penyuluh bebas menentukan media sosial mana yang lebih efektif dan efisien sebagai media belajar mandiri penyuluh. Menurut Rahmadi (2016) ada lima pemanfaatan media sosial yaitu (1) bersosialisasi dan berjaring sosial; (2) mendukung pembelajaran; (3) menjalin pertemanan; (4) menjalin relasi bisnis; (5) membuat group diskusi. Sedangkan Nasrullah (2017) menyatakan bahwa media sosial dapat dimanfaatkan seseorang untuk saling membagi ide, bekerjasama, dan berkolaborasi untuk menciptakan kreasi, berpikir, berdebat, menemukan orang yang bisa menjadi teman baik, menemukan pasangan dan membangun sebuah komunitas.

Pemanfaatan media sosial dalam penelitian diartikan sebagai intensitas penyuluh yang melibatkan minat, perhatian dan kesadaran dalam melakukan aktivitas yang berhubungan dengan pendayagunaan media sosial sebagai media belajar, media informasi, mencari informasi, berdiskusi, menambah pertemanan dan relasi, dan mendapat peluang kerjasama. Pemanfaatan media sosial oleh penyuluh pertanian adalah intensitas mengakses media sosial atau gambaran berapa lama dan sering penyuluh pertanian menggunakan media sosial. Sebaran indikator pemanfaatan media sosial oleh penyuluh di Provinsi Kepulauan Riau secara jelas dapat dilihat pada Tabel 3.

Intensitas pemanfatan whatsapp secara umum berada pada rataan skor 78 (tinggi). Tingginya intensitas penggunaan whatsapp dikatakan penyuluh karena whatsapp memiliki karakteristik yang paling mudah cara aksesnya dan lebih akrab keseharian dibanding dengan instagram, facebook dan youtube. Melalui grup whatsapp, penyuluh mendapatkan berbagai informasi terkini terkait pertanian. Grup whatsapp yang dapat memberikan informasi pertanian dan sebagai media belajar penyuluh yaitu Perhimpunan

Tabel 3. Sebaran Pemanfaatan Media Sosial Oleh Penyuluh di Provinsi Kepulauan Riau Tahun 2019

\begin{tabular}{llrr}
\hline \multirow{2}{*}{ Pemanfaatan Media Sosial } & \multicolumn{1}{c}{ Kategori } & $\begin{array}{c}\text { Jumlah } \\
\text { (Orang) } \\
\text { n=90 }\end{array}$ & $\begin{array}{r}\text { Persentase } \\
\text { (\%) }\end{array}$ \\
\cline { 2 - 4 } Facebook & Sangat rendah (skor 4-28) & 15 & 17 \\
Rataan Skor 55 & Rendah (skor 29-53) & 30 & 32 \\
& Sedang (skor 54-78) & 35 & 39 \\
Whatsapp & Tinggi (skor 79-100) & 10 & 11 \\
Rataan Skor 78 & Sangat rendah (skor 7-29) & 4 & 4 \\
& Rendah (skor 30-52) & 6 & 7 \\
Youtube & Sedang (skor 53-75) & 33 & 37 \\
Rataan Skor 57 & Tinggi (skor 76-100) & 47 & 52 \\
& Sangat rendah (skor 11-32) & 18 & 20 \\
Instagram & Rendah (skor 33-55) & 37 & 31 \\
Rataan Skor 25 & Sedang (skor 56-78) & 7 & 41 \\
& Tinggi (skor 79-100) & 40 & 8 \\
& Sangat rendah (skor 4-28) & 36 & 44 \\
\hline Sumber: Data (skor 29-53) & 8 & 9 \\
\hline
\end{tabular}

Sumber: Data Primer Diolah (2019) 
Penyuluh Pertanian Indonesia (Perhiptani), Kontak Tani Nelayan Andalan (KTNA), kelembagaan penyuluh Kepri, dan whatsapp menagemen penyuluh yang ada di masingmasing kabupaten/kota. Informasi di whatsapp ada berbagai macam jenis konten, mulai dari perkembagan komoditas pertanian terbaru, teknik budidaya, pengolahan pasca panen, teknologi pertanian, pemasaran, dan akses permodalan. Sedangkan konten yang terkait kebijakan pertanian biasanya didapatkan melalui whatsapp group manajemen penyuluh.

Secara umum intensitas pemanfaatan facebook dan youtube memiliki rataan skor 55 dan 57 (kategori sedang). Media sosial facebook yang diakses penyuluh di Kepri yaitu group THL-TBPP Indonesia, group SDM Kementan, dan grup komuditaskomuditas seperti jahe, tomat, buah-buahan dan hortikultura, semuanya dirasakan penyuluh sangat banyak manfaatnya. Sedangkan media sosial youtube yang biasa diakses penyuluh yaitu pengendalian hama dan penyakit, pembuatan pupuk organik, teknik budidaya berbagai komoditas baru, perbanyakan tanaman, dan teknologi pertanian lainnya.

Media sosial yang paling rendah intensitas pemanfaatannya adalah instagram dengan nilai rataan skor 25 (sangat rendah). Hal ini dikarenakan persepsi penyuluh bahwa informasi pertanian di instagram dinilai penyuluh jumlahnya masih sedikit, kebanyakan disajikan cuma dalam bentuk gambar saja, dan itu kurang diminati penyuluh pertanian di lokasi penelitian.

Proses pembelajaran pertanian melalui akses media sosial merupakan suatu proses transformasi perilaku. Penyuluh pertanian masa sebelumnya lebih memilih media belajar dalam bentuk buku, majalah, radio, dan televisi, seminar dan pelatihan, kemudian di era media digital ini penyuluh dituntut untuk dapat menggunakan media sosial sebagai sumber belajar mandiri. facebook, whatsapp, instagram, dan youtube dapat dimanfaatkan sebagai sumber informasi pertanian, mulai dari informasi budidaya, pemasaran, pengolahan, serta teknologi terbaru di sektor pertanian. Dengan mengakses media sosial facebook misalnya, penyuluh dapat belajar budidaya tanaman jagung yang berhasil dikembangkan di suatu daerah. Salah satu penyuluh di Kota Batam menyampaikan bahwa media sosial dapat dimanfaatkan penyuluh sebagai media belajar dan mendapatkan berbagai informasi terkait usahatani, misalnya kalau penyuluh menemukan hama dan penyakit di lapangan, penyuluh cukup foto kemudian dishare ke media sosial, dengan memberikan pernyataan ini penyakit apa ya dan apa obatnya?, penyuluh tidak lama langsung dapat respon dari teman-teman penyuluh atau petani yang sudah berpengalaman. penyuluh langsung dapatkan solusinya, dan informasi tersebut sangat sesuai dengan kebutuhan penyuluh dan petani.

Keterdedahan pada media sosial dapat dilihat dari intensitas pengunaan media sosial oleh penyuluh pertanian. Berdasarkan pengamatan lapangan penyuluh rata-rata kurang dari tiga jam sehari dalam mengakses media sosial. Hasil penelitian menujukkan bahwa penggunaan media sosial sebagai media belajar dan sumber informasi masih dinilai rendah. Intensitas penggunaan media sosial yang tinggi dikategorikan jika lebih dari tiga jam per hari dan dikatakan rendah jika hanya menggunakan selama satu sampai tiga jam per hari (Juditha, 2011).

Padatnya aktifitas keseharian penyuluh dengan aktifitas penyuluhan menyebabkan mereka tidak terlalu terdedah dengan media sosial. Penyuluh tidak memiliki banyak waktu untuk mengakses semua media sosial dan informasi yang ada di dalamnya. Selain padatnya aktifitas sehari-hari, kualitas jaringan internet tidak begitu baik untuk pulau-pulau tertentu sehingga menyebabkan tidak ada sinyal. Hanya ada satu operator kartu handphone yang dapat menjangkau pulau-pulau terpencil. Temuan ini diutarakan salah satu penyuluh Kabupaten Lingga yang menjelaskan bahwa sinyal internet di lokasi tugas jelek sekali, kadang info yang sudah dikirim lewat whatsapp pada hari sebelumnya 
baru dapat masuk satu hari setelahnya, apalagi kalau informasi yang dikirim dalam bentuk file/gambar lebih sulit lagi masuknya. Layanan wifi gratis juga masih jarang di Desa Singkep.

Keterdedahan terhadap media komunikasi adalah mendengarkan, melihat membaca, atau secara lebih umum mengalami dan dengan sedikitnya ada perhatian minimal pada pesan media (Rakhmat, 2007). Keterdedahan media sosial di lokasi penelitian dilakukan dengan cara membaca, menonton, berdiskusi dan sharing pengalaman, bertanya, dan mencari peluang bisnis dan kerjasama di bidang pertanian. Penyuluh masih kurang memanfaatkan media sosial untuk berdiskusi, berdebat/berpendapat, dan mencari peluang bisnis atau kerjasama. Penyuluh memanfaatkan media sosial masih terbatas membaca dan menonton saja (pembaca pasif).

Facebook dan whatsapp merupakan media sosial yang paling sering diakses penyuluh untuk membaca konten pertanian dan youtube paling sering untuk menonton video, tetapi kadang informasi dalam bentuk video juga dapat diakses melalui facebook dan whatsapp. Ketiga media sosial tersebut, memiliki potensi yang sama dimanfaatkan penyuluh untuk membaca dan menonton konten informasi usaha tani, berdiskusi/sharing pengalaman usahatani, bertanya permasalahan usahatani, dan mencari peluang bisnis dan kerjasama dalam usahatani.

Berdasarkan pengamatan di lapangan media sosial seperti facebook, youtube, whatsapp sudah dimanfaatkan di untuk mengakses informasi tentang pertanian yaitu terkait teknis produksi/ budidaya, pemasaran, kebijakan, pengolahan pasca panen, pembiayaan/ permodalan, dan tidak jarang juga digunakan untuk mengakses cerita sukses usahatani. Facebook lebih sering dimanfaatkan untuk belajar teknik produksi/ budidaya dan pemasaran, youtube lebih sering digunakan untuk menonton video petani-petani sukses dalam pengembangan pertanian, whatsapp lebih sering dimanfaatkan untuk mendapatkan informasi terkait kebijakan pertanian dan arahan dari pimpinan. Media sosial juga dimanfaatkan penyuluh untuk mensosialisasikan dan sharing informasi terkait sistem cocok tanam, info cuaca, keadaan gelombang laut, dan suhu.

Fakta di lapangan, menunjukkan bahwa penyuluh masih kurang efektif dalam memanfaatkan media sosial baik facebook, whatsapp, youtube dan instagram yang ditunjukkan oleh: (a) rendahnya intensitas berdiskusi, berbagi informasi, bertanya/ pendalaman informasi, dan mencari peluang usahatani, media sosial kurang dimanfaatkan penyuluh untuk berinteraksi dengan sumber belajar seperti berdiskusi dengan peneliti terkait dengan teknologi spesifik lokasi, (b) Penyuluh hanya aktif memanfaatkan media sosial untuk membaca informasi dan menonton video saja, namun masih kurang melakukan pendalaman informasi pertanian yang telah diterimanya, (c) materi/informasi pertanian yang diterima penyuluh melalui media sosial dalam bentuk file yang berkapasitas besar jarang didownload oleh penyuluh, kalaupun sempat biasanya didownload pada saat penyuluh mendapatkan fasilitas wifi gratis, dan (d) penyuluh masih belum fokus dalam mengakses informasi pertanian berbasis media sosial, informasi/konten didapatkan penyuluh melalui media sosial belum diakses/dibaca secara utuh bahkan kadang hanya dibaca judulnya saja.

Muslihat, et. al. (2015) menjelaskan bahwa kompetensi seorang penyuluh agar bisa dipandang berkompeten oleh masyarakat tergantung pada faktor konsumsi media. Semakin sering seorang penyuluh memanfaatkan media, maka semakin banyak pengetahuan yang dimiliki, dan kesempatan untuk menjawab permasalahan petani juga menjadi semakin besar. Dalam hal ini, media sosial sebagai media online yang dapat dimanfaatkan penyuluh secara mudah dalam mengakses informasi, menciptakan pesan, memberi komentar, dan berpendapat yang berinteraksi dan berpartisipasi yang dilakukan 
dengan berjejaring sosial secara cepat dan tidak terbatas termasuk konten pertanian. Penyuluh dapat terlibat dalam proses produksi, pengolahan, dan distribusi informasi. Di samping itu kecepatan, keakuratan, aktualitas, dan kuantitas yang besar, serta kemudahan dalam komunikasi menjadi tuntutan yang penting untuk meraih prestasi kerja penyuluh. Kehadiran teknologi informasi khususnya media sosial menawarkan alternatif sebagai media belajar bagi penyuluh pertanian. Media sosial memiliki banyak sumber informasi termasuk infomasi yang terkait dengan konten pertanian.

\section{Pengaruh Karakteristik Penyuluh terhadap Pemanfaatan media Sosial Sebagai Media Informasi Pertanian}

\section{Evaluasi Model Pengukuran (Outer Model)}

Model pengukuran atau Outer model merupakan evaluasi model untuk melihat hubungan antara variabel dengan indikator yang dapat dilihat dari nilai validitas konvergen, validitas diskriminan, dan konsistensi internal atau Cronbach's alpha, reliabilitas gabungan (Santosa, 2018). Dalam penelitian ini indikator diukur memalui indikator reflektif dan pembahasannya sebagai berikut:

1. Validitas konvergen

Hasil analisis menunjukkan bahwa terdapat dua indikator memiliki nilai loading factor $<0,7$. Masing-masing indikator ada di kedua variabel penelitian, yaitu indikator pendidikan formal pada variabel karakteristik penyuluh, dan indikator instagram pada variabel pemanfaatan media sosial. Artinya bahwa indikator tersebut tidak merefleksikan masing-masing peubah laten sehingga dikeluarkan (dropping) dari model. Pengujian reliabilitas

menunjukkan

seluruh

konstruk/variabel yang diukur pada penelitian ini memiliki nilai cronbach's alpha, composite reliability dan AVE rata-rata $>0.7$. Hasil tersebut merujuk pada teori (Santosa, 2018) maka dapat dikatakan semua konstruk reliabel.

2. Validitas diskriminan

Hasil analisis menunjukkan bahwa untuk setiap indikator yang berada pada suatu konstruk yang diwakili lebih besar nilainya dibandingkan dengan indikator kepada konstruk lain dengan rata-rata nilai cross loading untuk masing-masing indikator $>0.7$. Hasil tersebut sudah memenuhi kriteria Santosa (2018) yang menyatakan untuk masingmasing indikator nilai cross loading> 0.7 sehingga validitas diskriminan dalam penelitian ini dinyatakan valid.

\section{Evaluasi Model Struktural (Inner Model)}

Evaluasi model struktural merupakan pengukuran untuk menjawab tujuan penelitianyakni menganalisis pengaruh karakteristik penyuluh terhadap pemanfaatan media sosial sebagai media informasi pertanian. Pengujian model struktural dengan cara uji koefisien determinasi, uji GoF (Goodness of Fit) dan uji path coefficients untuk menguji hipotesis yang diajukan. Dalam penelitian ini menggunakan 1 hipotesis dan pengujiannya dapat dilakukan dengan cara Bootstraping pada software SmartPLS V.3.0.

1. Uji Koefisien Determinasi (R square)

Uji koefisien determinasi merupakan salah satu uji untuk melihatkorelasi antar konstruk dengan melihat nilai $R$-square $>0.25$ yang artinya menunjukkan pengaruh yang tinggi (Santosa, 2018). Nilai koefisien, tstatistik dan signifikansi variabel bebas yang

Tabel 4. Nilai Koefisien, t-statistik dan Signifikansi Variabel Bebas yang Mempengaruhi Variabel Terikat Tahun 2019

\begin{tabular}{ccccc}
\hline Variabel Bebas & Koefisien jalur & t-statistik & $\mathrm{p}$-value & Variabel terikat \\
\hline Karakteristik penyuluh & 0.705 & 15.319 & 0.000 & $\begin{array}{c}\text { Pemanfaatan media } \\
\text { sosial }\left(\mathrm{R}^{2=} 0,491\right)\end{array}$ \\
\hline
\end{tabular}

Sumber : Data Primer (2019) Diolah 
mempengaruhi variabel terikat dapat dilihat pada Tabel 4.

\section{Uji GoF (Goodness of Fit)}

Pengujian GoF (Goodness of Fit) digunakan untuk mengevaluasi model secara keseluruhan. Mengacu pada hasil analisis, nilai SRMR (Standardized Root Mean Residual) yaitu 0.082 maka model dinyakatakan fit. Hasil tersebut merujuk dari teori (Ghozali, 2015) model persamaan struktural dapat dikatakan fit jika nilai SRMR $<0,10$ dan model dinyatakan tidak layak jika nilai $\mathrm{SRMR}>0.15$. Nilai Chi-square diperoleh sebesar 48.627 maka data empiris yang digunakan dalam penelitian ini sangat identik dengan teori yang digunakan, karena Chi-square memiliki rentang nilai $>0.05$. Nilai NFI (Normed Fit Index)diperoleh sebesar 0.842 maka mengindikasikan model yang baik, karena rentang nilai NFI $<0.90$. Dari hasil nilai SRMR, Chi-square dan NFI maka model dalam penelitian ini sudah fit.

\section{Path Coefficient}

Uji Path Coefficients dalam model struktural dilakukan dengan melihat relasi/koefisien jalur konstruk laten yang satu dengan konstruk laten yang lain sesuai dengan hipotesis yang diajukan. Tingkat signifikansi relasi antar konstruk dapat dilihat dari nilai t-hitung (t-statistik) $>$ t-tabel (1.96) dengan taraf signifikansi sebesar 5\% $(0,05)$. Hasil pengujian hipotesis dapat ditunjukkan bahwa karakteristik penyuluh secara langsung mempengaruhi pemanfaatan media sosial dengan nilai t-statistik sebesar $15.319>\mathrm{t}$ tabel (1.96) dengan taraf signifikan p-value sebesar (0.000) dengan koefisien jalur positif sebesar 0.705, maka $\mathrm{Ha}$ diterima. Berdasarkan hasil analisis model pengaruh variabel karakteristik penyuluh terhadap pemanfaatan media sosial dapat dilihat dari Gambar. 1 sebagai berikut :

Variabel karakteristik penyuluh direfleksikan dengan indikator umur, pengalaman bekerja sebagai penyuluh, dan kosmopolitan. Nilai koefisien, t-statistik dan signifikansi indikator pada variabel karakteristik penyuluh yang memengaruhi pemanfaatan media sosial dapat dilihat secara jelas pada Tabel 5 .

Berdasarkan Tabel 5 nilai koefisien jalur indikator umur sebesar 0.796 , nilai t-statistik $>$ t-tabel (1.96) pada taraf nyata 0.000 . Hal ini menunjukkan bahwa umur berperan penting bagi penyuluh dalam pemanfaatan media sosial. Artinya semakin tua usia penyuluh, maka semakin meningkat pemanfaatan media sosial sebagai media belajar dan sumber informasi pertanian. Penyuluh dengan umur yang lebih tua lebih aktif memanfatkan media sosial untuk mencari informasi pertanian, dapat berdiskusi dan berdebat terkait masalah usahatani, dan aktif mencari peluang kerjasama usahatani. Sedangkan responden dengan usia muda cenderung pasif dalam pemanfaatan media sosial, belum berani mengutarakan pendapat lebih banyak, dan kurang intensif dalam memberikan informasi pertanian. Hasil penelitian ini berbeda dengan penelitian yang dilakukan Listiana (2018)

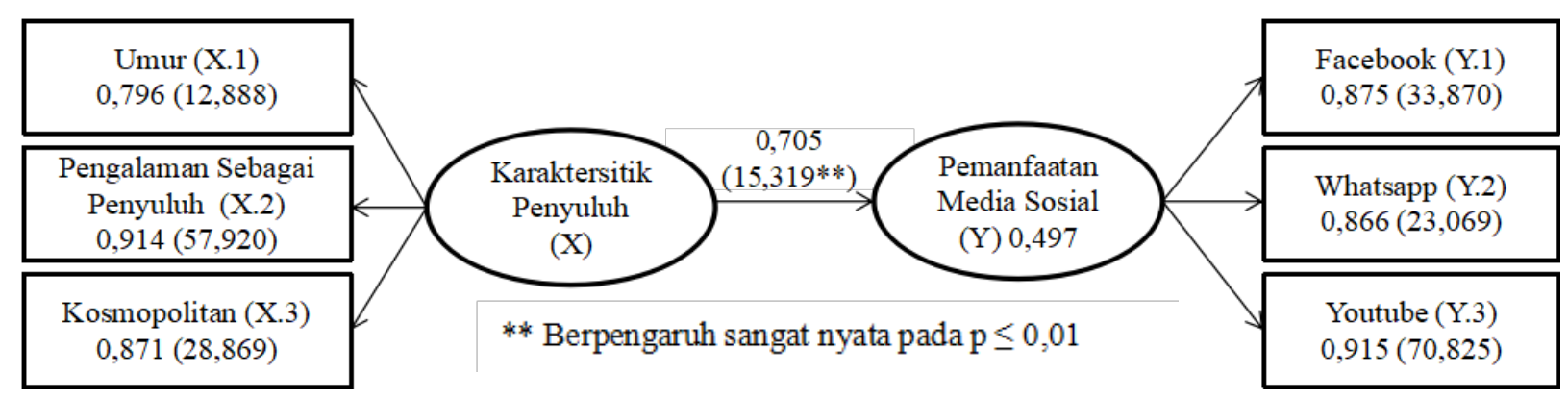

Gambar 1. Hasil PLS Pengaruh karakteristik penyuluh terhadap pemanfaatan media sosial Sumber: Data Primer Diolah (2019) 
Tabel 5. Nilai Koefisien, t-statistik dan Signifikansi Indikator pada Variabel Karakteristik Penyuluh Tahun 2019

\begin{tabular}{lccc}
\hline Indikator Karakteristik Penyuluh & Koefisien jalur & t-statistik & p-value \\
\hline Umur & 0.796 & 12.888 & 0.000 \\
Pengalaman sebagai penyuluh & 0.914 & 57.920 & 0.000 \\
Kosmopolitan & 0.871 & 28.869 & 0.000 \\
\hline
\end{tabular}

Sumber : Data Primer Diolah (2019)

yang menyatakan bahwa umur memiliki hubungan negatif dengan pemanfaatan TI.

Pengalaman kerja penyuluh yang memiliki nilai koefisien jalur sebesar 0.914, nilai t-statistik > t-tabel (1.96) pada taraf nyata 0.000 . Hal ini juga terbukti berkontribusi pada variabel karakteristik penyuluh dalam mempengaruhi pemanfaatan media sosial. Artinya semakin lama pengalaman bekerja sebagai penyuluh, maka semakin meningkat pemanfaatan media sosial sebagai media belajar dan sumber informasi pertanian. Pengalaman merupakan salah satu cara pengembangan kepribadian penyuluh yang dialami dalam kurun waktu yang tidak ditentukan. Penelitian Arifianto, et al. (2017) membuktikan bahwa pengalaman dapat mempengaruhi seseorang dalam menjalankan tupoksinya. Menurut Bird (2001), pembelajaran yang diperoleh dari pengalaman memberikan kemampuan (ability) bagi seseorang untuk: (1) belajar dari pengalaman yang berasal dari kegagalan dan keberhasilan, (2) merefleksikan pengalaman dengan melibatkan ego, emosi dan asumsi untuk melihat apa yang akan terjadi, (3) mengabstraksi pengalaman yang dialami dan menghubungkan dengan pengalaman orang lain, kemudian membuat prediksi apa yang akan dilakukan, dan (4) mencoba sesuatu yang baru pada masa yang akan datang.

Nilai koefisien jalur indikator kosmopolitan sebesar 0.871 , nilai t-statistik $>$ t-tabel (1.96) pada taraf nyata 0.00. Hal tersebut membuktikan bahwa sifat kosmopolitan penyuluh ikut berperan penting pada variabel karakteristik penyuluh dalam mempengaruhi pemanfaatan media sosial sebagai media belajar dan informasi pertanian.Artinya semakin tinggi tingkat kekosmopolitan penyuluh, maka semakin meningkat pemanfaatan media sosial sebagai media belajar dan sumber informasi pertanian. Penyuluh dengan jiwa kosmopolit lebih tinggi mengakses media sosial untuk mencari informasi pertanian, diantaranya digunakan untuk berkomunikasi dengan perhiptani, KTNA (Kontak Tani dan Nelayan Andalan), mengakses cyber extension kemudian dibagikan ke media sosial, menggunakan aplikasi startup pertanian, dan berkomunikasi dengan dinas pertanian dan BPTP untuk memberi informasi akan berkunjung ke kantor. Hasil penelitian ini berbeda dengan penelitian yang dilakukan Listiana (2018) menunjukkan semakin tinggi kosmopolitan penyuluh, maka kecenderungan penyuluh dalam intensitas penggunaan dan tingkat pengelolaan TI semakin kecil. Pendidikan formal dalam penelitian ini tidak berpengaruh terhadap pemanfaatan media sosial. Semakin tinggi pendidikan formal penyuluh, tidak memengaruhi penyuluh untuk semakin tinggi dalam intensitas pemanfaatan media sosial. Penyuluh yang berpendidikan formal tinggi maupun yang rendah belum memiliki kesadaran yang baik untuk terus belajar dengan memanfaatkan berbagai media belajar. Belajar tidak hanya melalui pendidikan formal, tetapi dengan memanfaatkan berbagai media yang ada di sekitar penyuluh baik media konvensional, media sosial, maupun media lingkungan.

\section{SIMPULAN DAN SARAN}

Berdasarkan pada analisis data yang telah dilakukan, maka dapat diambil beberapa kesimpulan dan saran sebagai berikut : 


\section{Kesimpulan}

Secara umum di Provinsi Kepulauan Riau intensitas penyuluh dalam memanfaatan media sosial sebagai media informasi pertanian masih kategori sedang. Secara khusus intensitas pemanfatan media sosial yaitu; (1) facebook kategori sedang, (2) whatsapp kategori tinggi, (3) youtube kategori sedang, dan (4) instagram kategori rendah. Pemanfaatan media sosial ini dipengaruhi oleh karakteristik penyuluh yang terefleksikan dari umur, pengalaman bekerja sebagai penyuluh, dan kosmopolitan. Pendidikan formal tidak mampu memengaruhi penyuluh untuk meningkatkan pemanfaatan media sosial sebagai media belajar dan informasi pertanian. Penyuluh yang berpendidikan rendah dan tinggi belum memiliki kesadaran yang baik untuk terus belajar dengan memanfaatkan media sosial sebagai media informasi pertanian.

\section{Saran}

Adapun saran yang dapat penulis berikan sesuai hasil penelitian adalah sebagai berikut:

1. Perlu lebih meningkatkan dan memperluas pengalaman bekerja sebagai penyuluh.

2. Perlu membangun kesadaran penyuluh pertanian untuk terus belajar secara bertahap, berkualitas dan berkelanjutan terkait usahatani salah satunya melalui pemanfaatan media sosial.

3. Perlu diberikan informasi kepada penyuluh bahwa di media sosial instagram juga banyak informasi pertanian yang dapat diakses oleh penyuluh.

\section{DAFTAR PUSTAKA}

Anwas, O. M. 2009. Pemanfaatan Media dalam Pengembangan Kompetensi Penyuluh Pertanian (Kasus di Kabupaten Karawang dan Garut Provinsi Jawa Barat). Disertasi. Sekolah Pasca Sarjana Institut Pertanian Bogor.
Arifianto, S., S. Satmoko dan B.M. Setiawan. 2017. Pengaruh Karakteristik Penyuluh, Kondisi Kerja, Motivasi Terhadap Kinerja Penyuluh Pertanian Dan Pada Perilaku Petani Padi Di Kabupaten Rembang. Jurnal Agrisocionomics. 1(2): 166-180.

Bahua, M.I., dan M. Limonu. 2016. Model pengembangan kompetensi penyuluh pertanian di Provinsi Gorontalo. Journal Of Social And Agricultural Economics. 9(1): 13-19.

Bird, C. 2001. Menulis dengan Emosi. Terjemahan Eva Y. Nukman. Bandung: Kaifa

Effendi, S dan Tukiran. 2012. Metode Penelitian Survei. Jakarta: LP3ES.Ghazali I. 2015. Struktural Equation Modeling Metode Alternatif dengan Partial Least Square. Semarang: Badan Penerbit Undip.

Hartati, P., M.Y. Surung, Sudirman, dan A. Wahab. 2011. Analisis Kinerja Penyuluh Pertanian di Kabupaten Bantaeng Sulawesi Selatan. Jurnal Agrisistem. 7(2): 1-11.

Hubeis, A.V.S. 2010. Perilaku Masyarakat dalam Pemanfaatan Information and Communication Technology dalam Mendukung Pengembangan Masyarakat Global. Jurnal Komunikasi Pembangunan. 8(2): 2335 .

Juditha, C. 2011. Hubungan penggunaan situs Jejaring Sosial Facebook terhadap Perilaku Remaja di Kota Makasar. Jurnal Ilmu Pengetahuan dan Teknologi Komunikasi. 13(1): 1-23.

Lako, A dan A. Sumaryati. 2002. Optimalisasi Kinerja Korporasi Melalui Audit Kinerja Manajemen Sumber Daya Manusia. Jurnal Usahawan No.10. TH.XXXI. 
Listiana, I. 2018. Pengaruh pemanfaatan teknologi informasi terhadap kapasitas penyuluh di Provinsi Lampung. Disertasi. Sekolah Pasca Sarjana Institut Pertanian Bogor.

Muslihat, E., A. Azhar, K. Kusmiyati dan W. Indriatmi. 2015. Kompetensi Penyuluh Pertanian dalam Penyusunan Rancangan Usaha Agribisnis Padi pada BKP5K Kabupaten Bogor Provinsi Jawa Barat. Agriekonomika. 4(2): 132-153.

Nasrullah, R. 2017. Media Sosial: Perspektif Komunikasi, Budaya, Dan Sosioteknologi. Bandung: Simbiosa Rekatama Media.

Puntoadi, D. 2011. Meningkatkan Penjualan Melalui Sosial Media. Elex Gramedia.

Rahmadi, A. 2016. Tips Produktif Ber-Social Media: Memanfaatkan Aneka Sosial Media Populer, Riset Sosial Media, Promosi Online. Jakarta: PT Elex Media Komputindo.

Rakhmat, J. 2007. Psikologi Komunikasi. Bandung: PT Remaja Rosda Karya.

Santosa, P. I. 2018. Metode Penelitian Kuantitatif-Pengembangan Hipotesis dan Pengujiannya Menggunakan SmartPLS. Yogyakarta. CV. Andi Offset.

Tukiran, T dan M. Hidayati. 2012. Penelitian Kuantitatif. Bandung: Alfabeta.

Veronice. 2013. Pemanfaatan teknologi informasi dan komunikasi dalam peningkatan kompetensi penyuluh. Tesis. Sekolah Pasca Sarjana Institut Pertanian Bogor.

Wearesosial dan Hootsuite. 2019. Pengguna Media Sosial di Indonesia Mencapai 150 Juta atau 56\% Dari Total
Populasi. Internet, [diunduh 2019 Februari 09] Tersedia pada: http://databoks.katadata.co.id/datapubl ish.

Wijaya, A. S. 2015. Pemanfaatan cyber extension sebagai media informasi oleh penyuluh pertanian di Kabupaten Bogor. Tesis. Sekolah Pasca Sarjana Institut Pertanian Bogor. 
